Uşak Üniversitesi Sosyal Bilimler Dergisi

$2014,7 / 4$

\title{
Kullanıcıların Facebook Reklamlarına Tepkilerini Belirleyen Reklam Özellikleri
}

\author{
Vesile ÇAKIR* \\ Mehmet Sinan TAM*
}

\begin{abstract}
Özet
Facebook halihazırda en popüler sosyal medyadır ve bu özelliği ile cazip bir reklam medyasıdır. Bu araştırma facebook reklamlarının beğenilmesi, tıklanması ve paylaşılmasında yordayıcı olan reklam özelliklerini araştırmaktadır. Facebook kullanıcıları üzerinde gerçekleştirilen bir saha araştırmasından elde edilen veriler, kullanıcıların ilgilendikleri bir ürün kategorisine ait, tıklanma oranının yüksek, bilim kurgu tarzı, değişik renk ve yazılı bağlantılara sahip ödemeli reklamlara daha çok tıkladığını ortaya koymaktadır. Ayrıca her ödemeli reklam satın alma davranışına yol açmamaktadır. Kullanıcılar daha çok karşı cinsin yer aldığı, reklamverenin kimliğini açıkça göremedikleri, "son fırsat", "hemen tıkla kazan" gibi çekici çağrıların yer aldığı, dikkat çekici ikonları olan, ilgilendikleri bir ürün/hizmetin reklamlarına tıklayarak satın alma davranışını gerçekleştirmektedirler. Facebook haber akışı içerisinde yer alan reklamların beğenilmesinde ise reklamın komik olması, fiyat avantajı vaat etmesi, beğenilen markalara ait, yabancı ve cinsel içeriğe sahip olması önemli olmaktadır.
\end{abstract}

Anahtar Kelimeler: Ödemeli Facebook Reklamları, Facebook Haber Akışı Reklamları, Tıklama, Beğenme, Paylaşma, Satın Alma Davranışı.

\section{Advertisement Features Determining the Users' Reactions to Facebook Advertisements}

\begin{abstract}
Facebook is the most popular social media medium and because of this it is a suitable advertisement media. This survey studies advertisement features which are predictor on liking, clicking and sharing of Facebook advertisements. That is why; this survey was conducted on Facebook users. According to findings of the survey; compared to the others, users prefer to click to Facebook advertisements which have more clicking rates, interests of

* Doç. Dr., Uşak Üniversitesi, İletişim Fakültesi, Halkla İlişkiler ve Reklamcılık Anabilim Dalı

** Marmara Üniversitesi, Sosyal Bilimler Enstitüsü, İletişim Bilimleri Anabilim Dalı
\end{abstract}


users, different colors, design styles and connections. Moreover, every on delivery advertisement results in purchasing behavior. Users mostly realize purchasing behaviors by clicking a product's or service's advertisements including opposite sex, no information about advertiser, attractive icons, calls such as "last chance", "click and win" etc. Being funny, offering good price, having sexual content and belonging well-known brands are so important for the advertisements in Facebook news stream to be liked by people.

Key Words: On Delivery Facebook Advertisements, Facebook News Stream Advertisements, Clicking, Like, Purchasing Behavior.

\section{Giriş}

Bugün çoğu insan için internet kullanımının en taze ve canlı kategorisi insanların arkadaşları ve meslektaşları ile iletişim ve bağlantı kurabildiği, yenileri ile tanışabildiği sosyal ağlar ya da sosyal web siteleridir. Facebook ise bugün itibari ile dünya genelinde 800 milyon kullanıcı ile sosyal ağlar içinde lider konumdadır. Bu sosyal medyanın üyeleri arkadaşları ile konuşabilmekte, fotoğraf, haber, video paylaşabilmekte, birbirlerinin durumlarına yorum yapabilmekte, gruplara katılabilmekte ve kendilerine göre önemli konular hakkında tartışabilmektedirler. Facebook insanların online oyun oynamaları, testler paylaşabilmeleri ve almalarını sağlayan ve bu site üzerinde çalışan üçüncü parti uygulamalara da sahiptir.

Tüm bu aktivitelerin yanında facebook herhangi birinin satın alabileceği, yaratabileceği, yayınlayabileceği reklamlara da sahiptir. Facebook kullanıcıları hakkında günlük oluşturulan zengin bir bilgi hazinesine sahiptir ve reklamverenlere kullanıcıların verilerinin gizliliğini etkilemeksizin bu bilgilere erişme imkânı sunmaktadır. Bu açıdan Facebook reklamverenlerin pazarlama, pazarlama iletişimi çalışmaları için geleneksel medyanın sunduğundan daha fazla imkân sunmaktadır. Öte yandan kullanıcılar da beğendikleri ürünler, markalar ve firmalar hakkında daha aktif olma, daha fazla bilgiye erişme imkânı bulmakta, bu markalar ve firmalar ile etkileşebilmekte, bunlar hakkında birbirleriyle tartışabilmekte, çoğu zaman da reklamverenlerin kampanyaları, ürünleri ve markaları hakkında konuşarak, beğenerek, bunlara ilişkin reklamları paylaşarak bu tür çabalara aktif olarak katılmakta ve gönüllü destek verebilmektedir. Böylelikle bu medya üzerinde başlatılan pazarlama ve reklam çabalarının etkisi katlanarak büyümektedir. 
Ancak tıpkı geleneksel medyada olduğu gibi, Facebook'ta da izlerkitle her reklama ya da her mesaja aynı tepkiyi vermemektedir. Neden bazı reklamlar daha çok tıklanırken, beğeni alırken ya da paylaşılırken bazıları bu açılardan zayıf kalmaktadır? Facebook üzerindeki ne tür reklamlar izlerkitleyi tıklamaya, beğenmeye ve reklamı paylaşmaya güdülemektedir? Bu çalışmada bu soruların cevaplarını bulmak amacıyla, Facebook kullanıcılarıyla, bu medya üzerinde gerçekleştirilen bir saha araştırmasının sonuçlarına yer verilmektedir.

\section{Sosyal Medya}

"Bireylerin sınırları belirlenmiş bir sistem içinde halka yarı/açık profil oluşturmasına, bağlantıda olduğu diğer kullanıcıların listesini açıkça vermesine, bu diğer kullanıcıların sistemdeki listelenmiş bağlantılarını görmesine ve aralarında gezmesine izin veren web tabanlı hizmetlerin tümüne sosyal ağlar denmektedir" (Büyükşener, 2009: 19). Kaplan ve Haenlein (2010: 61) literatürde sıklıkla yapıldığı gibi sosyal medyanın "kullanıcı türevli içerik" ve Web 2.0 ile aynı şey olmadığını belirterek sosyal medyayı, "Web 2.0 sistemi teknolojik temelleri üzerine kurulu, kullanıcı türevli içeriğin yaratılması ve değişimine izin veren internet tabanlı uygulamalar grubu" olarak tanımlar. İnternet mecrası başlarda geleneksel iletişim yöntemlerinin kullanılacağı tek yönlü bir iletişim sunarken Web 2.0 denilen gelişim, interneti bir paylaşım ortamına çevirmiş, kullanıcının diğer kullanıcılarla ve içinde bulunduğu ağ ile etkileşim kurmasına imkan tanıyarak sosyal ağların ortaya çıkışına zemin oluşturmuştur. Kullanıcılar, sosyal ağın başındaki kişilerin dışında onlara da tanıdığı içerik üretimi ve paylaşımı imkânını kullandığında ise, sosyal ağlar birer sosyal medyaya dönüşmüştür. 


\section{Tablo 1. Sosyal Medya Örnekleri}

- Sosyal paylaşım siteleri (MySpace, Facebook, Faceparty)

- Yaratıcı çalışmaları paylaşım siteleri:

- Video paylaşım siteleri (Youtube)

- Fotoğraf paylaşım siteleri (Flickr)

- Müzik paylaşım siteleri (Jamendo.com)

- Bilgi ve destek sağlayan içerik paylaşım siteleri (Piczo.com)

- Genel fikri mülkiyet paylaşım siteleri (teliflendirme siteleri) (Creative Commons): (Yaratıcı Müşterekler) Amerika'da kurulu, kişilerin paylaştıkları metaları internette insanlara açarken doğru bir biçimde, söz gelimi "her hakkı saklıdır" ya da "bazı hakları korunmaktadır" gibi farklı tiplerde lisanslandırmalarına ve eser sahibinin istediği oranda erişim sağlayabilmesine yarayan kullanımı kolay ve ücretsiz araçlar sunan, kar amacı gütmeyen kuruluşs.)

- Kullanıcı destekli bloglar (Resmi olmayan Apple Weblog, Ccnet.com)

- Firma destekli websiteler/bloglar (Apple.com)

- Firma destekli kampanya/yardım siteleri (Dove'un Real Beauty kampanya sitesi, click2quit.com)

- Sadece davetli sosyal ağlar (AsmallWorld.net)

- İşa ağ1 siteleri (Linkedln)

- İşbirliğine dayalı websiteleri (Wikipedia)

- Sanal dünyalar (Second Life)

- Ticaret toplulukları (eBay, Amazon.com, Craig's List vb.)

- Podcast ağları: For Immediate Release: The Hobson and Holtz Report (forimmediaterelease.biz)

- Haber dağıtım siteleri (Current TV)

- Eğitim materyali paylaşım siteleri (MIT OpenCourseWare, MERLOT)

- Açık kaynak software toplulukları (Mozilla'nın spreadfirefox.com, Linux.org)

- Kullanıcıların online haber, müzik, video vb. tavsiye etmelerini sağlayan sosyal imleme siteleri (Digg, del.icio.us, Nesvine, Reddit)

*Çevirenin notu

Kaynak: Mangold and Faulds David J. (2009). "Social Media: The New Hybrid Element of the Promotion Mix", Business Horizons, 52: 358. 
Günümüz modern toplumlarında, sosyal medya neredeyse yaşamın ayrılmaz bir parçasıdır. Üniversite öğrencilerine yönelik gerçekleştirilen bir araştırma bunu kanıtlamaktadır. Göker ve arkadaşlarının (2010: 192) yaptığı bir araştırmaya göre araştırmaya katılanların \%77'si Facebook'a üyedir. Önceden üye olupta üyeliğini iptal edenler ise deneklerin sadece \%16'sıdır.

Facebook, Twitter, Google, Youtube vb. sosyal mecraların bu kadar hızlı yayılması ve benimsenmesinin altında belirgin sebepler vardır. Üyeliklerin ücretsiz olması ve internetin gittikçe ucuzlaması, erişim yollarının çeşitlenmesi, kullanım kolaylığı, sosyal medyanın kullanıcıların önemli bazı gereksinimlere cevap vermesi belli başlı sebepler arasındadır. Sosyal medya haber ve bilgi edinme, çevreyle bilgi paylaşma vb. bilişsel gereksinimlerin yanı sıra, eğlenme, yalnızlıktan kurtulma ve sosyalleşme, sorunlardan kaçınma/başetme, boş zaman geçirme/eğlenme, narsizim, benlik sunumu gibi psikolojik ve sosyal psikolojik gereksinimleri tatmin etmenin alternatif yoludur. Sosyal medyanın kullanıcılara sunduğu bazı daha somut avantajlar da onun benimsenmesi ve kullanımının gittikçe yayılmasının sebepleri arasındadır. Zafarmend (2010: 10-11)'e göre, katılım, açıklık, konuşma imkanı (iki yönlü iletişim), topluluk oluşturabilme, bağlanma ve online kültür oluşturabilme, içerik oluşturabilme ve böylece yeni etkileyenler tabakasına dahil olabilme olanakları, Vrilio (2003: 14)'ya göre, evrensellik, ücretsiz olma, sanal kimlik oluşturabilme olanakları, Papic ve Noonan (2011: 167-172)'a göre, eleştirellik, alıcıdan kaynak konumuna geçebilme, hedef kitleye kolayca ulaşabilme avantajları da sosyal medya nüfusunun kartopu gibi büyümesini sağlamaktadır.

\section{Sosyal Medya ve Pazarlama}

Sosyal medyanın/ağların sayılan özellikleri ve kullanım avantajları sadece bireysel kullanım açısından düşünülmemelidir. Siyasetçiler, işdünyası, kurumlar, firmalar başta Facebook, Friendfeed, Twitter olmak üzere sosyal ağları kullanarak, kampanyalarına, politik veya kurumsal imajlarına güç katmakta ya da maddi kazanç elde etmektedir.

Sosyal medya günümüzde kişilerarası iletişim, siyasi iletişim, kitle iletişimi, kurumsal iletişim alanlarını kadar, pazarlama ve pazarlama iletişimi faaliyetlerini de dönüştürmektedir. Sosyal medya ürün ve hizmetlerin pazarlanması ve reklamının yapılma şeklinde devrim yaratmıştır. Şirketler sosyal medyayı kullanarak bir kaç yıl öncesinde mevcut olmayan yeni reklam ve promosyon yollarına sahip olmuşlardır. Sosyal medya ile şirketler oldukça hızlı ve kolaylıkla reklam kampanyaları ve promosyonlar yaratabilmekte ve uygulayabilmektedir. Ayrıca pazarlama 
ve reklam çabalarına tüketicinin katılımı bu sayede artmaktadır (Mon, 2013: 43).

Blackshaw ve Nazzaro (2006: 2)'ya göre, sosyal medya pazarlama açısından kullanıcı türevli medyadır/içeriktir. Tüketici türevli medya birbirlerini ürünler, markalar, hizmetler, kişiler ve sorunlar hakkında eğitme amacıyla tüketiciler tarafından yaratılan, başlatılan, dolaştırılan ve kullanılan çeşitli yeni online enformasyon kaynaklarıdır. Tüketici türevli içerik, tüketiciden tüketiciye email, internet üzerinde tartışma panoları ve forumlar, tüketici derecelendirme siteleri ya da forumlar ve bloglar (webloglar ya da dijital günlükler), kullanıcıların mobil telefonlar ya da kablosuz ağlar üzerinden dijital, resim, fotoğraf yayınladığı mobloglar, sosyal ağ web siteleri ve kişisel web sitelerini içeren ama bunlarla sınırlı olmayan online ağızdan ağıza iletişim araçlarına ve yöntemlerine gönderme yapar. Mangold ve Faulds (2009: 357)'a göre, sosyal medya firmaların müşterileri ile konuşmalarını sağladığı gibi, bir taraftan da müşterilerin doğrudan doğruya birbirleri ile konuşmalarını sağladığı için, pazarlama iletişimi karmasının bir hibrid elemanıdır. Sosyal medyada tüketiciler arasındaki sohbetin sıklığı, zamanlaması ve içeriği yöneticinin doğrudan kontrolünde değildir. Bu durum yüksek bir kontrol derecesinin olduğu geleneksel bütünleşik pazarlama iletişimi paradigmasına zıttır. Bu yüzden, yöneticiler tüketiciler arasındaki tartışmaları kurumların misyonları ve amaçları ile tutarlı bir tarzda şekillendirmeyi öğrenmek zorundadır. Bunu yapmanın yolları ise, tüketicilere ağ platformları sağlamak, blogları, sosyal medya araçlarını ve tüketicilerin ilgisini çekebilecek promosyonel araçları kullanmaktır. Blackshaw ve Nazzaro (2006: 2)'ya göre, tüketici türevli içerik/medya ve bunun özel bir aracı olarak sosyal medyada online ağızdan ağıza iletişim geleneksel pazarlamacılar ve pazarlama aktiviteleri tarafından başlatılmış ya da etkilenmiş bile olsa tüketicilerin kontrolünde ve sahipliğindedir ve belki de bu yüzden geleneksel medyadan daha güvenilirdir. Bu durum pazarlamacılara önemli fırsatlar sunmaktadır.

Facebook, Twitter ve Google+ gibi sosyal paylaşım sitelerinin içeriği çok iyi düzenlenmiştir ve Google, Yahoo Search gibi arama motorlarında üst sıralardadır. Pazarlama uzmanları arama motorlarında üst sıralarda oldukları ve büyük bir genç kullanıcı kitlesine sahip oldukları için sosyal paylaşım sitelerine reklam vermeyi tavsiye etmektedir. Honda, HP, Apple, Polmolive, IBM vb. uluslararası markalardan birçok daha küçük markaya kadar, markalar, şirketler, kurumlar, en yeni ürünlerini sergilemek, hedef 
kitlelerine erişmek için sosyal paylaşım sitelerinde aktif olarak yer almaktadır. Sosyal paylaşım sitelerini kullanmak bu şirketlerin arama motoru optimizasyonunu yükseltmekte, hedef kitlelerin ürün ve hizmetlerine erişimini arttırmaktadır. Bu sitelerde pazarlama birbirlerine ulaşma fırsatı sunduğundan hem pazarlamacılar hem de tüketiciler için avantajlıdır (Goyal, 2012: 17).

Sosyal medya ve özellikle de Facebook hem doğrudan pazarlama hem de ilişki pazarlaması için oldukça elverişlidir. Sosyal medyada spesifik bir reklam ya da reklam kampanyası daha çok bir doğrudan pazarlama çabasıdır. Öte yandan facebook reklamları ile etkileşimler firmanın mail listesine eklenen yeni kişi sayısını arttırmak, facebook iş sayfasının hayran sayısını arttırmak, firmasının Facebook postlarını yapılan yorumların ve beğenmelerin miktarını tespit etmeye yarar (Dunay, Krueger ve Elad, 2011: 19-22).

"Sosyal pazarlama" ya da "sosyal medya pazarlaması" sosyal medyada iki biçimde gerçekleşmektedir: (1) Facebook, Twitter ya da YouTube gibi sosyal medyanın ücretsiz araçlarını kullanarak, (2) bu tür sosyal medyaya ödeme yapmak suretiyle reklam yayınlatarak ya da blog içeriklerine sponsor olarak. Nielsen Vizu'nun 2013 raporuna göre, reklamverenlerin $\% 89^{\prime} u$, ajansların $\% 71^{\prime}$ i ücretsiz sosyal medya araçlarını kullanmaktadır. Reklamverenlerin \%75'i ve ajansların \%81'i ise sosyal medyada ödemeli reklam yapmakta ve/veya içeriklere sponsor olmaktadır. Ödemeli sosyal medya reklamcilığ hala görece yeni bir uygulamadır. Reklamverenlerin \%71'i, ajansların ise \%66'sı online reklamlarını sıklıkla sosyal reklamlarla desteklediklerini belirtirken, reklamverenlerin \%51'i ve ajansların \%41'i offline reklamlarını sosyal reklamlar ile desteklemektedirler (Paid Social Media Advertising Report, 2013).

\section{Facebook'ta Reklam}

Sosyal ağlar medya platformuna dönüşünce bu platform için iletişim yöntemlerinin gelişmesi de kaçınılmaz olmuştur. Geleneksel medyada olduğu gibi sosyal medyada da öncüler reklam alanından çıkmıştır. Reklam ajansları dijital platformlar için yeni yapılanmalara gitmişler, hatta sadece dijital platformlara yönelik reklam ve pazarlama çalışmaları yapan "dijital ajans"lar kurulmuştur. Tüm bunların sonucu olarak da sosyal medyada etkileşimli reklam, advergame denilen reklam temelli oyunlar ve daha pek çok uygulama hayata geçmiştir (Büyükşener, 2009: 22). Bireysel kullanıcıların da birer içerik üreticisi ve yayıcısı olduğu düşünüldüğünde sosyal medya üzerindeki reklama önem vermemek günümüz şartlarında 
stratejik bir hata olmaktadır. Firmaların, kişilerin, kurumların geleneksel iletişim ortamları için kurdukları iletişim ve reklam stratejilerinin destekleyicisi ve uzantısı olarak ya da sadece sosyal medyaya özgü kampanyalar için yoğun çaba harcamaları gerekmektedir. Ancak sosyal medyada bu tür kampanyalarda harcanan çaba, para ve zamanın karşıllı̆ 1 büyük olmaktadır. Çünkü firmaların sosyal medyada başlattıkları kampanyalar, promosyon ya da etkinlik duyuruları aktif kullanıcıların zincirleme reaksiyonu sayesinde, daha az emekle daha çok kişiye ulaşabilmektedir. Kullanıcılar markaların, kampanyalarının gönüllü iletişimcisi haline gelmektedir.

Facebook kullanıcılarına birbirleriyle birebir ilişki kurabilme, özel arkadaş grupları oluşturabilme ve seçilen kişilerle resim ve video paylaşımı yapabilme imkânı sunmaktadır. Teknik olarak kullanıcı Facebook'ta durum güncellemesi yaptığında ya da duvarına bir şey eklediğinde bu hareketler kullanıcının arkadaşlarının haber akışında görünmektedir. Kullanıcının arkadaşları da kendi bağlantılarını gönderebilmektedirler. Kullanıcı bir resim, video vb. eklediğinde arkadaşları bunu beğenebilmekte, paylaşabilmekte, yorum yapabilmektedir. Ayrıca güncellemelerin tarihi de gösterilmektedir. Facebook kullanıcılarına arkadaşları ile canlı chat imkânı da sunmaktadır. Tüm bunların yanında arkadaşların doğum günleri, etkinlikleri vb. de kullanıcıya haber olarak gösterilmektedir (Goyal, 2012: 17). Facebook'un kullanıcıya sunduğu bu teknik imkânlar, etkileşimde bulunmanın ve orada olmanın hazzını ve gerçekçiliğini arttırmaktadır. Facebook'un bireysel kullanıcılara sunduğu bu imkânları kurumlar ve firmalar da pazarlama ve pazarlama iletişimi amaçları için kullanabilmektedir. Onlar da kendi sayfalarını açabilmekte, kurumlarının, ürünlerinin, markalarının haberlerini duyurabilmekte, özel kampanyalarını, promosyonlarını Facebook üzerinden yürütebilmektedirler.

Önemli bir reklam mecrası olan Facebook'un promosyon rehberi şirketlerin kendi promosyonlarında Facebook'un özelliklerini ne kadar kullanabileceklerini sınırlamaktadır. Geçmişte, Facebook şirketlerin tüm promosyonlarını uygulamalar aracılığıyla yönetmelerini şart koşuyor, bir sayfayı beğenme sonucu oluşan bir girişe, bir yerin denetimine ya da bir uygulamaya bağlanmaya izin vermiyordu. Ama son zamanlarda Facebook promosyon rehberini yenilemiştir. Artık promosyonlar Facebook zaman tünelinden de yönetilebilmektedir ve ayrıca şirketler artık, kullanıcıların bir sayfadaki gönderileri, yorumları ve beğenileri, mesajlarını kullanarak girdi 
toplayabilmekte, oylama mekanizmalarını kullanabilmektedirler (Mon, 2013: $50)$.

Facebook reklamverenlere farklı seçenekler sunmaktadır. Şu an geçerli sisteme göre Facebook reklamları şu şekilde sınıflandırılabilir (Dunay, Krueger ve Elad, 2011: 82-84):

$\checkmark$ Harici Web Site Reklamları: Bu reklamlar diğer pek çok online sisteme benzer biçimde çalışır. Reklamcı bir başlık, reklam mesajı yazar ve uygun bir imaj seçer. Kullanıcı reklama tıkladığı zaman, reklamda sunulan tekliflerin detaylarının yer aldığı bir dış web siteye erişir.

$\checkmark$ Facebook Sayfa Reklamları: Hayran reklamları olarak da bilinirler. Bu reklamlar bir Facebook iş sayfasını destekler. $\mathrm{Bu}$ reklamların amacı kullanıcinın bu tür Facebook sayfalarını beğermelerini ya da bunların bir fanı olmalarını sağlamaktır.

$\checkmark$ Olay Reklamları: Bu reklamlar yakında meydana gelecek bir olay, kampanya vb. hakkında farkındalık oluşturmaya çalışır. Reklamveren bu tür reklamlarla günlük hediyeleri, yakındaki indirimleri, fırsatları duyurabilir.

$\checkmark$ Grup Reklamları: Facebook sayfa reklamlarına benzer şekilde, kullanıcı yöneticisi olduğu bir Facebook grubunu desteklemek için bu tür bir reklam yaratabilir. Bu reklamların amacı grubu tanıtmak, gruba yeni üyeler kazandırmaktır.

$\checkmark$ Uygulama Reklamları: Bir Facebook uygulamasının yaratıcısı diğer kullanıcıların denemelerini istedikleri, kendi profillerinde kurmalarını istedikleri mevcut bir Facebook uygulamasının tanıtımı için reklam yapabilir.

$\checkmark$ Anket Reklamları: Bu reklamlar kullanıcılara seçtikleri bir konuda kanılarını sunma ya da oylama yapma imkânı sunar. Anket reklamları tıklandığı zaman oylayıcıyı seçilen sayfaya yönlendirir. Bu şekilde sadece değerli araştırma bilgisine ulaşılmaz, aynı zamanda kullanıcı markaya aktif olarak katılmaya da teşvik edilir.

$\checkmark$ Video Reklamlar: $\mathrm{Bu}$ reklamlar tıklandığı zaman kullanıcının belirli bir reklamı izlemesini sağlar. Hedef izler kitlenin reklamı izlemesini sağlamak için videoyu oynatacak yeni bir pop up penceresi açlır. Videolar paylaşılabilir, beğenilebilir ve tekrar tekrar izlenebilir. 
$\checkmark$ Hediye Reklamları: Bu reklamlar izleyicinin arkadaşlarına hediye gönderip göndermeme ya da göndereceği hediyeye karar vermesini sağlar. Bu hediyeler kullanıcının sayfasında gösterilir ve Facebook kullanıcıları hangi arkadaşlarının hediye gönderdiğini, hediye için arkadaşlarının söylediklerini görebilirler.

Goyal (2013: 222) ise Facebook reklamlarını (1) Facebook reklamları, (2) Promoted Post'lar, (3) Sponsorlu Haberler, (4) Sayfa Gönderisi Reklamları, (5) Facebook Nesnesi (Like) Reklamlar ve (6) Harici Web site Reklamları şeklinde sınıflar. Literatürde farklı şekillerde, Goyal ve Duncan ve arkadaşlarınınkine benzer başka sınıflandırmalar da bulunmaktadır. Her sosyal ağın reklam sistemi farklı çalışmaktadır. Bu tür sınıflamalar Facebook'un reklam sistemini anlamak için yararlıdır. Ancak konunun burada ele alınışı bakımından daha basit bir sınıflandırma daha kullanışlı olacaktır. Facebook üzerindeki reklamlar en genel şekliyle iki ana başlık altında sınıflanabilir: (1) Ödemeli/sponsorlu Facebook reklamları ve (2) haber akışı reklamları.

\section{1. Ödemeli/Sponsorlu Facebook Reklamları}

Facebook reklamları, uygulamalar, fotoğraflar, gruplar, sayfalar, profiller (zaman tünelleri) ve ana sayfa dâhil olmak üzere pek çok tür sayfada belirebilen, bu sayfaların sağ taraftaki sütununda yer alan reklamlardır (Facebook, 2014). Bu alan Facebook'un reklamverenlere bedel karşılığı pazarladığı bir alandır. O yüzden burada yer alan reklamlara "pazarlama alanı Facebook reklamları" (Mestçi, 2013) da denmektedir. Bu tarz Facebook reklamlarının dört türü vardır (Mestçi, 2013: 131-132): (1) Pazarlama alanı standart reklam (2) pazarlama alanı etkinlik reklamları, (3) pazarlama alanı like (beğen) reklamları, (4) pazarlama alanı uygulama reklamları.

Facebook'taki her ödemeli ya da sponsorlu reklamın dört unsuru vardır (Dunay, Krueger ve Elad, 2011: 10): (1) Başlık (25 ya da daha az karakter), (2) İmaj (ölçüsü opsiyonel olmakla birlikte en çok tavsiye edileni 110x80 pixels), (3) reklam metni ya da mesaj (135 karakter ya da daha az), (4) Facebook'a ya da başka bir web sayfasına bir link (reklama tıklandığı zaman aktif olan). Facebook reklamlara "Like" linki ekler. Reklamveren bir Facebook iş sayfasını destekliyorsa "Like" linkine tıklamak bir fan olarak kullanıcıyı firmanın Facebook iş sayfasına yönlendirecektir.

Facebook reklamları Facebook'un ücretsiz kullanılmasını sağlar ve bu yüzden tamamen engellenemez. Ancak kullanıcı sağ sütunda görünen 
herhangi bir reklamın sağ üst köşesindeki "kapat" ikonuna tıklayarak "bu reklamı görmek istemiyorum" seçeneğini işaretleyerek belirli bir reklamı engelleyebilir. Ya da içeriğinden rahatsız olduğu bir reklamı şikâyet edebilir. Facebook reklamlarında, kullanıcının Facebook reklamları gelişigüzel değil, planlı bir hedef kitle bölümlemesine göre göstermektedir. Kullanıcıların ilgilerini çekebilecek reklamları gösterebilmek için kullanıcıların paylaştı̆̆ bilgiler (örn., beğenilen sayfalar, ilgi alanları, işyeri, okul vb.), yaş, cinsiyet, konum gibi demografik bilgiler, Facebook'a erişirken kullanılan cihazlar, reklamverenlerin ve Facebook'un pazarlama ortaklarının kullanıcı ile ilgili sahip olduğu ve Facebook ile paylaştığı bilgiler, ABD'de yaşayanların Facebook dışındaki diğer sitelerdeki eylemleri ile ilgili bilgilere göre hedefleme yapılmaktadır. Sponsorlu reklamların etkinliği kullanıcı hakkında toplanan bilgilerin değerlendirilmesi ile doğrudan bağlantılıdır (Facebook, 2014).

Firmalar sponsorlu reklamlara özellikle kampanya dönemlerinde başvurmakta, küçük bütçelerle geniş kitlelere ulaşabilmektedirler. Kara ve Coşkun (2012: 80)' un Facebook üzerinde sponsorlu reklam türünden reklamlar veren giyim firmaları ile gerçekleştirdiği mülakatların sonucuna göre, Facebook'ta reklama tıklayan tüketicilerin özellikle gerçek mağazalardaki kısa vadede satın alma şeklindeki dönüş oranları düşüktür. $\mathrm{Bu}$ reklamlar daha çok tüketicinin firmaların Facebook sayfasıyla tanışmasını sağlayarak firma bilinirliğini arttırmaktadır ve firmalarca bu amaçla kullanılmaktadır. Ancak araştırmaya katılan firmalar bu tür reklamların sanal ortamdaki satış noktalarındaki çevrimiçi satışları arttırdığını da belirtmektedirler (Kara ve Coşkun, 2012: 80).

\subsection{Haber Akışı Reklamları}

Kullanıcı kendisine gösterilen bir reklam üzerinde "beğen"e tıkladığında o reklamdaki işletme, marka veya ürünle bir bağlantı oluşturur. $\mathrm{Bu}$ beğenme zaman tünelinde gösterilir ve kullanıcının arkadaşları haber kaynağında bunun hakkında bir haber görebilir. Ayrıca beğenilen sayfa hakkındaki güncellemeler de haber kaynağında görülebilir. Bir hesap sahibi diğerlerinin yaptığı bir reklamı beğenme eylemlerini kendi haber kaynağında gördüğünde bir reklamda arkadaşlarının adını ve fotoğrafının yer aldığını da görebilir. Bunlara "sponsorlu haberler" de denilmektedir. Bu sponsorlu haberler Facebook reklamları ile birlikte verilmektedir (Facebook, 2014). Haber kaynağında bu tür "haber reklamlar" yanında, Facebook'un yayınlamadığı, kullanıcıların kendi inisiyatifleri ile Facebook'a yükledikleri veya paylaştıkları, yani reklam yayıncısının kullanıcının bizzat kendisinin olduğu reklamlar da yer alır. Bu reklamların kaynakları ise çeşitlidir: Facebook üzerindeki başka sayfalar; bir kullanıcının kendi haber 
kaynaklarına gelmiş reklamlar; internet üzerinde bir video paylaşım sitesi, bir kurumun kurumsal web sitesi vb. gibi herhangi bir sitede yeralan Facebook bağlantılı reklamlar; kullanıcının kendi bilgisayarlarında depoladığı ya da bizzat kendisi ya da bir grup tarafından hazırlanmış reklamlar.

\section{Metodoloji}

\subsection{Amaç}

Çalışmanın ana amaçlarından biri, Facebook'un bir reklam yayıncısı olarak kendisinin yayınladığı reklamların hangi özelliklerinin (linkli reklamlar) tıklama ve satın alma davranışının gerçekleştirilmesini sağlamada daha önemli olduğunu bulmaktır. Ancak bir sosyal medya olarak Facebook kullanıcılarına reklam izleyicisi olmanın yanında birer reklam yayıncısı olma imkânı da sunmaktadır. Kullanıcıların paylaştığı ve haber akışında yayınlanan reklamların hangi özelliklerinin bu reklamların beğenilmesinde, paylaşılmasında ve satın alma davranışının gerçekleştirilmesinde etkili olduğunu bulmak bu çalışmanın bir diğer ana amacidır.

\section{2. Örneklem}

Günümüzde sosyal medya mecraları çeşitli formatlarda ve spesifik alanlarda kendini göstermektedir. Sosyal medya mecraları arasında en çok kullanıcıya sahip olan, buna bağlı olarak da reklam faaliyetlerinin görüldüğü ve bu mecralar arasında ana kütleyi en iyi temsil ettiği düşünülen Facebook kullanıcıları, araştırmanın örneklemini oluşturmaktadır. Anketin cevaplayıcılarının Facebook kullanıcısı olması gerektiğinden, örneklem amaçlı örneklem yöntemi ile oluşturulmuştur. Facebook kullanıcılarına ulaşma bakımından en elverişli yol ise anketi Facebook üzerinden gerçekleştirmektir. Facebook üzerinden mesaj ile diğer kullanıcılara gönderilen anketlere 450 geri dönüş sağlanmış, toplamda 431 anket geçerli kabul edilmiştir.

\subsection{Araştırma soruları}

S1: Facebook'un kendisinin yayınladığı (linkli) reklamların çeşitli özellikleri (animasyon, bilimkurgu, ilgilenilen ürün/hizmet, ihtiyaç, son fırsat türü çağrılar, bağlantı, tıklanma oranı, renkler, metin ve başlık, logosuz, görseller, ikonlar, karşı cins) birlikte bu reklamlara tıklama davranışının anlamlı birer yordayıcısı mıdır?

S2: Facebook'un kendisinin yayınladığı (linkli) reklamların çeşitli özellikleri (animasyon, bilimkurgu, ilgilenilen ürün/hizmet, ihtiyaç, son 
fırsat türü çağrılar, bağlantı, tıklanma oranı, renkler, metin ve başlık, logosuz, görseller, ikonlar, karşı cins) birlikte bu reklamlara (linklere) tıklayarak alışveriş yapma davranışının anlamlı birer yordayıcısı mıdır?

S3: Haber akışı reklamlarının çeşitli özellikleri (komik, şaşırtıcı, ilginç, farklı, zekice, müzik, ünlü oyuncu, marka, ürün/hizmet, haber değeri, yabancı, fiyat avantajı, yeni ürün, cinsellik, toplum yararı) birlikte bu reklamları beğenme (like etme) davranışının anlamlı birer yordayıcısı mıdır?

S4: Reklamların çeşitli özellikleri (komik, şaşırtıcı, ilginç, farklı, zekice, müzik, ünlü oyuncu, marka, ürün/hizmet, haber değeri, yabanc1, fiyat avantajı, yeni ürün, cinsellik, toplum yararı) birlikte Facebook'ta reklam paylaşma davranışının anlamlı birer yordayıcısı mıdır?

S5: Haber akışı reklamlarına tıklama, beğenme ve paylaşma davranışı birlikte reklamı yapılan markaları satın alma davranışının anlamlı birer yordayıcısı midır?

\subsection{Veri Toplama Araçları}

Facebook Reklamlarına Tıklama Davranışı: Facebook önemli bir reklam yayıncısıdır. Facebook'un ikili ticari anlaşmalar ile kendisinin yayınladığı reklamlar kullanıcının sayfasının sağında ve solunda kalan alanlarda gösterilmektedir. Deneklerin Facebook reklamlarına tıklama davranışı "Facebook reklamlarına tıkladığım olur" şeklindeki 5 noktalı (1 Kesinlikle katılmıyorum, 5 Tamamen katıliyorum) Likert tipi madde ile ölçülmüştür.

Ödemeli (Sponsorlu) Facebook Reklamlarına Tıklama Davranışında Rol Oynayan Reklam Özellikleri: Facebook'un kendisinin yayınladığ 1 reklamlara tıklama davranışında önemli olabilecek reklam özelliklerini kestirebilmek amacıyla deneklerden, 5 noktalı (1 Önemsiz, 5 Çok önemli) Likert tipi 13 maddede siralanan reklam özelliklerinin kendi Facebook'un yayınladığı reklamlara tıklama davranışları üzerindeki önem derecesini belirtmeleri istenmiştir. Söz konusu Facebook reklamı özelliklerini niteleyen maddeler şu şekildedir: Facebook reklamının "...animasyon tarzında olması", "...bilim kurgu tarzında olması", "...ilgilenilen bir ürün/hizmet kategorisinde olması", "...ihtiyaç duyulan şeylerle ilgili olması", "... 'son fırsat', 'sınırlı sayıda' vb. çağrılar içermesi”, “...değişik renkli, altı çizili bağlantıları olması”, " ...tıklanma oranının yüksek olması", "...renklerinin hoşa gitmesi", "...metninin ve başlığının ilgi çekici olması", "...reklam verenin logosunun olmaması", “... görsellerinin iyi olması”, “...dikkat çekici ikonlarının olması”, “...karşı cinse yer vermesi".

Ödemeli (Sponsorlu) Facebook Reklamlarını Tıklayarak Alışveriş Yapma Davranışı: Facebook'un kendisinin yayınladığı reklamlara tıklayıp bağlantılı siteye giderek alışveriş yapma davranışı “Facebook'un yayınladığı 
reklamlara tıklayarak alışveriş yaptığım olur" şeklindeki 5 noktalı (1 Kesinlikle katılmıyorum, 5 Tamamen katıliyorum) Likert tipi madde ile ölçülmüştür.

Ödemeli (Sponsorlu) Facebook Reklamlarına Tıklayarak Alışveriş Yapma Davranışında Önemli Olan Reklam Özellikleri: Facebook'un kendisinin yayınladığı reklamlara tıklayarak alışveriş yapma davranışında önemli olabilecek reklam özelliklerini kestirebilmek amacıyla deneklerden, 5 noktalı (1 Önemsiz, 5 Çok önemli) Likert tipi 13 maddede sıralanan reklam özelliklerinin kendi Facebook'un yayınladığı reklamlara tıklama davranışları üzerindeki önem derecesini belirtmeleri istenmiştir. Söz konusu Facebook reklamı özelliklerini niteleyen maddeler şu şekildedir: Facebook reklamının "...animasyon tarzında olması", "...bilim kurgu tarzında olması", "...ilgilenilen bir ürün/hizmet kategorisinde olması", "...ihtiyaç duyulan şeylerle ilgili olması", "... 'son fırsat', 'sınırlı sayıda' vb. çağrılar içermesi”, “...değişik renkli, altı çizili bağlantıları olması", “ ...tıklanma oranının yüksek olması", "...renklerinin hoşa gitmesi", "...metninin ve başlığının ilgi çekici olması", "...reklam verenin logosunun olmaması", “... görsellerinin iyi olması", “...dikkat çekici ikonlarının olması", “...karşı cinse yer vermesi”.

Facebook'ta Haber Akışı Reklamlarını Beğenme Davranışı (Like Butonuna T1klama): Facebook kullanıcıları Facebook'un kendisinin yayınladığı reklamlar dışında kendi ana sayfalarındaki haber akışı içinde, takip ettikleri firmaların, arkadaşlarının vb paylaştığı reklamlarla da karşılaşmaktadırlar. Bunlar çoğunlukla reklam videoları şeklinde olmakla birlikte, bağlantılar, hareketsiz görüntüler şeklinde de olabilmektedir. Bu çalışmada bu tarz reklamlar kısaca "haber akışı reklamları" olarak ifade edilmiştir. Deneklerin Facebook'un kendisinin yayınladıkları dışındaki bu tarz reklam beğenme davranışı "Facebook'un yayınladıkları dışındaki kendi haber akışı sayfamdaki reklamları beğendiğim olur (like'larım)" şeklindeki 5 noktalı (1 Kesinlikle katılmıyorum, 5 Tamamen katılıyorum) Likert tipi madde ile ölçülmüştür.

Haber Akışı Reklamlarının Beğenilmesinde (Like'lanmasında) Rol Oynayan Reklam Özelikleri: Bu çalışmada yayıncısının Facebook olmadığı, haber akışında görüntülenen reklamların beğenilmesinde önemli olabilecek reklam özellikleri belirlenmek istenmektedir. Bu amaçla deneklerden, 5 noktalı (1 Önemsiz, 5 Çok önemli) Likert tipi 15 maddede sıralanan reklam özelliklerinin kendi like etme davranışları için önem derecesini belirtmeleri istenmiştir. Haber akışı reklamları özelliklerini niteleyen maddeler şu şekildedir: Haber akışı reklamlarımın "...komik olması", “...şaşırtıcı olması”, 
"...ilginç olması, "...farklı olması", "zekice tasarlanmış olması", "...müziği”, “...ünlü oyuncuların oynaması", “...sevdiğim markalarla ilgili olması", “...ilgilendiğim ürün/hizmetlerle ilgili olması", “...önemli bir haber vermesi (haber değeri), "...yabanc1 olması", "...fiyat avantajından bahsetmesi", “...piyasaya yeni çıan bir ürünü duyurması", "... cinsel içerikli olması", “...mesajının toplum yararı içermesi".

Facebook'ta Reklam Paylaşma Davranışı: Deneklerin Facebook'ta reklam paylaşma davranışı "Facebook'ta reklam paylaşırım" şeklindeki 5 noktalı (1 Kesinlikle katılmıyorum, 5 Tamamen katılıyorum) Likert tipi madde ile ölçülmüştür.

Facebook'ta Reklam Paylaşma Davranışını Yordayan Reklam Özellikleri: Bu çalışmada Facebook kullanıcılarının kendi sayfalarında reklam paylaşma davranışlarında belirleyici olan reklam özellikleri belirlenmeye çalışılmaktadır. Başka bir deyişle kullanıcıların ne tür reklamları paylaşma eğiliminde oldukları ve paylaştıkları araştırılmaktadır. $\mathrm{Bu}$ amaçla deneklerden, 5 noktalı (1 Önemsiz, 5 Çok önemli) Likert tipi 17 maddede sıralanan reklam özelliklerinin kendi reklam paylaşma davranışları için önem derecesini belirtmeleri istenmiştir. Reklam özellikleri ile ilgili maddeler şöyle sıralanmaktadır: Reklam paylaşma davranışımda “...reklamın komik olması", “...şaşırtıcı olması", “...ilginç olması", “...farklı olması", “...zekice tasarlanmış olması", “...müziğini beğenmem”, “...ünlü oyuncuların oynaması", "...sevdiğim markalarla ilgili olması", "...ilgilendiğim ürün/hizmet ile ilgili olması", "...haber değeri olması", "...yabancı bir reklam olması", "...fiyat avantajı sunması", "...yeni bir ürünle ilgili olması", “...cinsel içerikli olması", “...toplum yararına olması", “...bir yeniliği duyurması", “...son fırsat, sınırlı sayıda, hemen tıkla kazan gibi ibareler içermesi".

Haber Akışı Reklamlarındaki Ürünleri/Markaları Satın Alma Davranışı: Facebook'un kendisinin dışında kullanıcıların yayınladıkları reklamlarda yer alan ürünleri/markaları satın alma davranışı “Facebook'ta başkalarının/arkadaşlarımın yayınladığı reklamlarda yer alan ürün/markaları satın aldığım olur" şeklindeki 5 noktalı (1 Kesinlikle katılmıyorum, 5 Tamamen katılıyorum) Likert tipi madde ile ölçülmüştür.

Haber Akışı Reklamlarındaki Ürünleri/Markaları Satın Alma Davranışının Belirleyicileri: Bu çalışmanın amaçlarından biri, deneklerin Facebook üzerinde kullanıcıların paylaştığı reklamları beğenme, tıklama ve paylaşma davranışlarının bu reklamlardaki ürün/markaları herhangi bir yerde ve zamanda satın alma davranışında belirleyici olup olmadığını kestirebilmektir. Başka bir deyişle deneklerin reklamları beğenme, tıklama ve paylaşma davranışlarının reklamlardaki ürün/markaları satın almalarına 
yol açıp açmadığı araştırılmaktadır. Bu amaçla deneklerden "Facebook'ta arkadaşlarımın paylaştı̆̆ı reklamları beğendiğim olur", "Facebook'ta arkadaşlarımın paylaştığı reklamlara tıkladığım olur" ve "Facebook'ta reklam paylaştığım olur" şeklindeki 5 noktalı (1 Hiç Katılmıyorum, 5 Tamamen katılıyorum) Likert tipi üç maddeye katılma derecelerini belirtmeleri istenmiştir.

\section{Bulgular ve Yorum}

Araştırma sorularının cevaplanabilmesi için toplam 431 anket ile elde edilen veriler SPSS 16.0 istatistik programı kullanılarak, frekans ve doğrusal çoklu regresyon analizleri gerçekleştirilmiş, analiz sonuçlarının bulguları aşağıda sunulmuştur.

\subsection{Demografik Bulgular}

Ülkemizde en sık kullanılan sosyal medya olarak Facebook kullanıcılarına yönelik bu araştırma için Facebook üzerinden gerçekleştirilen ankete 431 denek katılmıştır. Örneklemin yaş, cinsiyet, medeni hal, gelir, eğitim durumu ve Facebook'ta geçirilen süre ile ilgili dağılımları Tablo 2'de gösterilmektedir. 
Tablo 2. Deneklerin Demografik Özellikleri

\begin{tabular}{|c|c|c|c|c|c|}
\hline & Frekans & $\%$ & & Frekans & $\%$ \\
\hline \multicolumn{3}{|l|}{ 1. Cinsiyet } & $1501-3000 \mathrm{TL}$ & 151 & 35,0 \\
\hline Kadın & 252 & 58,5 & $3001-4500 \mathrm{TL}$ & 35 & 8,1 \\
\hline Erkek & 179 & 41,5 & $4501-6000 \mathrm{TL}$ & 39 & 9,0 \\
\hline \multicolumn{3}{|c|}{ 2. Medeni Durum } & 6001 TL ve üstü & 8 & 1,9 \\
\hline Bekar & 354 & 82,1 & \multicolumn{3}{|l|}{ 6. Meslek } \\
\hline Evli & 77 & 17,9 & Serbest meslek & 32 & 7,4 \\
\hline \multicolumn{3}{|l|}{ 3. Yaş } & Memur & 80 & 18,6 \\
\hline 18 ve altı & 15 & 3,5 & İşçi & 63 & 18,6 \\
\hline $19-29$ & 318 & 73,8 & Sanayici-Tüccar & 4 & 0,9 \\
\hline $30-40$ & 75 & 17,4 & Emekli & 2 & 0,5 \\
\hline $41-50$ & 15 & 3,5 & Ev kadını & 12 & 2,8 \\
\hline 51 ve üstü & 8 & 1,9 & Öğrenci & 223 & 51,7 \\
\hline \multicolumn{3}{|c|}{ 4. Eğitim Durumu } & İşsiz & 15 & 3,5 \\
\hline İlk ve ortaokul & 7 & 1,6 & \multicolumn{3}{|l|}{$\begin{array}{l}\text { 7.Facebook'ta } \\
\text { (haftalık) }\end{array}$} \\
\hline Lise & 60 & 13,9 & $1-10$ saat & 286 & 66,4 \\
\hline Önlisans & 10 & 2,3 & $11-20$ saat & 68 & 15,8 \\
\hline Lisans & 286 & 66,4 & 21-30 saat & 40 & 9,3 \\
\hline Yüksek lisans & 50 & 11,6 & $31-40$ saat & 12 & 2,8 \\
\hline Doktora & 18 & 4,2 & $41-50$ saat & 9 & 2,1 \\
\hline \multicolumn{3}{|c|}{ 5. Gelir Durumu } & 51 saat ve üstü & 16 & 3,7 \\
\hline 1500 TL ve altı & 198 & 45,9 & Toplam & 431 & $\begin{array}{l}100, \\
0\end{array}$ \\
\hline
\end{tabular}

\section{2. Ödemeli (Sponsorlu) Reklamların Özellikleri ve T1klama}

\section{Davranışı}

Araştırmanın amaçlarından biri Facebook'un bir reklam yayıncısı olarak pazarlama alanında kendisinin yayınladı̆̆ 1 ve başka bir web sitesine, içeriğe, uygulamaya link veren ne tür reklamların bu reklamlara tıklanma davranışında önemli olduğunu bulmaktır. Bu amaçla bu tür reklamlar için söz konusu olabilecek çeşitli reklam özelliklerinin her biri ile tıklama 
davranışı değişkeni arasında Çoklu Doğrusal Regresyon Analizi gerçekleştirilmiştir (Tablo 3).

Tablo 3. Ödemeli (Sponsorlu) Reklamlara Tıklama Davranışının Yordanmasına İlişkin Çoklu Regresyon Analizi Sonuçları

\begin{tabular}{|c|c|c|c|c|c|c|c|}
\hline Değişken & B & $\begin{array}{c}\text { Standart } \\
\text { Hata B }\end{array}$ & $\beta$ & $\mathrm{T}$ & $\mathrm{p}$ & İkili r & K1smi r \\
\hline Sabit &,- 134 & ,125 & - & $-1,078$ & 282 & - & - \\
\hline $\begin{array}{l}\text { 1. Reklamin } \\
\text { animasyon tarzı } \\
\text { olması }\end{array}$ & ,037 & ,053 & ,040 & 694 & ,488 & ,518 & ,023 \\
\hline $\begin{array}{l}\text { 2. ...bilim kurgu } \\
\text { tarzı olması }\end{array}$ & 137 & ,052 & 150 & 2,638 & ,009 &, 531 & ,089 \\
\hline $\begin{array}{l}\text { 3. ...ilgilenilen bir } \\
\text { ürün/hizmet } \\
\text { kategorisinde } \\
\text { olması }\end{array}$ & 200 & ,058 & ,226 & 3,450 & ,001 & ,518 & ,116 \\
\hline $\begin{array}{l}\text { 4. ...ihtiyaç duyulan } \\
\text { şeylerle ilgili olması }\end{array}$ & ,042 & ,057 & ,048 & 739 & ,460 &, 512 & ,025 \\
\hline $\begin{array}{l}\text { 5. ..."Son firsat", } \\
\text { "sınırlı sayıda" vb. } \\
\text { çağrılar içermesi }\end{array}$ & ,085 & ,052 & ,081 & 1,640 & 102 & ,499 & ,055 \\
\hline $\begin{array}{l}\text { 6. ...değişik renkli, } \\
\text { altı çizili } \\
\text { bağlantıları olması }\end{array}$ & 157 & ,067 & 142 & 2,341 & ,020 & ,575 & ,079 \\
\hline $\begin{array}{l}\text { 7. ...tıklanma } \\
\text { oranının yüksek } \\
\text { olması }\end{array}$ & 203 & ,058 & 200 & 3,521 & ,000 & ,596 & 119 \\
\hline $\begin{array}{l}\text { 8. ..kullanilan } \\
\text { renklerinin hoşa } \\
\text { gitmesi }\end{array}$ & ,056 & ,054 & ,056 & 1,044 & 297 & ,509 & ,035 \\
\hline $\begin{array}{l}\text { 9. ..metninin ve } \\
\text { başlığının ilgi } \\
\text { çekici olması }\end{array}$ &,- 020 & ,048 &,- 023 &,- 415 & ,678 & ,513 &,- 014 \\
\hline $\begin{array}{l}\text { 10...reklam verenin } \\
\text { logosunun } \\
\text { olmaması }\end{array}$ & ,044 & ,055 & ,036 & 790 & ,430 & ,436 & , 027 \\
\hline $\begin{array}{l}\text { 11... görsellerinin } \\
\text { iyi olması }\end{array}$ & ,062 & ,057 & ,070 & 1,091 & ,276 & ,509 & ,037 \\
\hline $\begin{array}{l}\text { 12...dikkat çekici } \\
\text { ikonlarının olması }\end{array}$ &,- 074 & ,056 &,- 083 & $-1,310$ & 191 & ,480 &,- 044 \\
\hline $\begin{array}{l}\text { 13..karşı cinse yer } \\
\text { vermesi }\end{array}$ & ,041 & ,053 & ,035 & ,774 & ,439 & ,394 & ,026 \\
\hline $\mathrm{R}=, 725 \quad \mathrm{R}^{2}=, 526$ & 13,417 & $=35,542$ & .000 & & & & \\
\hline
\end{tabular}


Ödemeli reklamlara ilişkin özellikler birlikte, bu tür reklamlara tıklama davranışı ile orta düzeyde anlamlı bir ilişki vermektedir $(R=0,725$, $\left.\mathrm{R}^{2}=0,526, \mathrm{p}<.01\right)$. Söz konusu değişkenler birlikte ödemeli reklamlara tıklamadaki toplam varyansın yaklaşık \% 53'ünü açıklamaktadır.

Standardize edilmiş regresyon katsayısına $(\beta)$ göre, yordayıcı değişkenlerin Facebook reklamlarına tıklama üzerindeki göreli önem sırası; $3,7,2,6,12,5,11,8,4,1,10,13,9$ numaralı değişkenler şeklindedir.

Tablo 3'de regresyon katsayılarının anlamlılığına ilişkin t-testi sonuçları incelendiğinde önem sırasına göre; "reklamın ilgilenilen bir ürün kategorisine ait olması", $\{\beta=.26, p<, 05\}$, "reklamın tıklanma oranının yüksek olması" $\{\beta=.20, p<, 01\}$, "reklamin bilim kurgu tarzında olması" $\{\beta=.15$, $\mathrm{p}<, 05\}$ ve "reklam bağlantılarının değişik renk ve yazıyla verilmiş olması" $\{\beta=.14, p<, 05\}$ değişkenlerinin Facebook reklamlarına tıklama davranı̧̧ı üzerinde anlamlı birer yordayıcı olduğu görülmektedir. Diğer değişkenler anlamlı birer yordayıcı değildir.

Regresyon analiz sonuçlarına göre Facebook reklamlarına tıklama davranışının yordanmasına ilişkin regresyon eşitliği ise aşağıda verilmektedir.

Facebook Reklamlarına (Linkli Reklamlara) Tiklama $=-0,134+0,37$ (animasyon) + 0,137 (bilimkurgu) + 0,200 (ilgi) + 0,042 (ihtiyaç) $+0,085$ (son firsat) $+0,157$ (renk) $+0,203$ (tıklanma ) + 0,056 (renkler) - 0,020 $($ metin/başlık) + 0,044 (logosuz) + 0,062 (görseller) - 0,074 (ikonlar) + 0,041 (karşı cins)

5.3. Ödemeli (Sponsorlu) Reklamların Özellikleri ve Bunlara Tıklayarak Alışveriş Yapma Davranışı

Araştırmanın bir diğer amacı, ödemeli Facebook reklamlarına tıklayarak reklamverenin sitesine gitme ve alışverişi gerçekleştirme davranışında belirleyici reklam özelliklerini tespit etmektir. Başka bir deyişle "sosyal medya söz konusu olduğunda ne tür reklamlar satışta daha başarılı olmaktadır?" sorusunun cevabı aranmaktadır. Bu amaçla bu tür reklamlar için söz konusu olabilecek çeşitli reklam özelliklerinin her biri ile alışveriş yapma değişkeni arasında Çoklu Doğrusal Regresyon Analizi gerçekleştirilmiştir (Tablo 4). 
Tablo 4. Ödemeli (Sponsorlu) Reklamlara Tıklayarak Alışveriş Yapma Davranıșının Yordanmasına İlișkin Çoklu Regresyon Analizi Sonuçları

\begin{tabular}{|c|c|c|c|c|c|c|c|}
\hline Değişken & B & $\begin{array}{c}\text { Standart } \\
\text { Hata B } \\
\end{array}$ & $\beta$ & $\mathrm{T}$ & $\mathrm{p}$ & İkili r & $\begin{array}{c}\text { Kismi } \\
\mathrm{r}\end{array}$ \\
\hline Sabit & 191 & 135 & - & 1,416 & 158 & - & - \\
\hline $\begin{array}{l}\text { 1.Reklamin } \\
\text { animasyon tarz1 } \\
\text { olmas1 }\end{array}$ & ,027 & ,057 & ,032 & ,469 & 639 & 290 & ,023 \\
\hline $\begin{array}{l}\text { 2....bilimkurgu tarzı } \\
\text { olması }\end{array}$ & ,014 & ,056 & ,016 & ,242 & ,809 & ,285 & ,012 \\
\hline $\begin{array}{l}\text { 3....ilgilenilen bir } \\
\text { ürün/hizmet } \\
\text { kategorisinde olması }\end{array}$ & 119 & ,063 & 145 & 1,897 & ,059 & 296 & ,092 \\
\hline $\begin{array}{l}\text { 4....ihtiyaç duyulan } \\
\text { şeylerle ilgili olması }\end{array}$ & ,090 & ,062 & 110 & 1,457 & 146 & ,300 & ,071 \\
\hline $\begin{array}{l}\text { 5....."son fırsat", } \\
\text { "sınırlı sayıda" vb. } \\
\text { çağrılar içermesi }\end{array}$ & 189 & ,056 & 196 & 3,371 & ,001 & ,458 & 163 \\
\hline $\begin{array}{l}\text { 6....değişik renkli, altı } \\
\text { çizili bağlantıları } \\
\text { olması }\end{array}$ &,- 002 & ,072 &,- 002 &,- 026 & 979 & ,430 &,- 001 \\
\hline $\begin{array}{l}\text { 7....tıklanma oranının } \\
\text { yüksek olması }\end{array}$ & ,043 & ,062 & ,046 & 693 & ,488 & ,431 & ,034 \\
\hline $\begin{array}{l}\text { 8....kullanilan } \\
\text { renklerinin hoşa } \\
\text { gitmesi }\end{array}$ & 112 & ,058 & 120 & 1,922 & ,055 & ,398 & ,094 \\
\hline $\begin{array}{l}\text { 9....metninin ve } \\
\text { başlığının ilgi çekici } \\
\text { olması }\end{array}$ &,- 109 & ,052 &,- 134 & $-2,101$ & ,036 & ,280 &,- 102 \\
\hline $\begin{array}{l}\text { 10....reklam verenin } \\
\text { logosunun olmaması }\end{array}$ & ,234 & ,060 & ,210 & 3,924 & ,000 & ,447 & 189 \\
\hline $\begin{array}{l}\text { 11.... görsellerinin iyi } \\
\text { olmas1 }\end{array}$ &,- 003 & ,061 &,- 003 &,- 042 & 966 & 299 &,- 002 \\
\hline $\begin{array}{l}\text { 12....dikkat çekici } \\
\text { ikonlarının olması }\end{array}$ &,- 139 & ,061 &,- 169 & $-2,284$ & ,023 & ,265 &,- 111 \\
\hline $\begin{array}{l}\text { 13....karşı cinse yer } \\
\text { vermesi }\end{array}$ & ,238 & ,058 & ,216 & 4,130 & ,000 & ,442 & 198 \\
\hline
\end{tabular}

Ödemeli reklamlara ilişkin özellikler birlikte, bu tür reklamlara tıklayarak satın alma davranışı ile düşük düzeyde anlamlı bir ilişki vermektedir $\left(R=0,594, R^{2}=0,352, p<.01\right)$. Söz konusu değişkenler birlikte, ödemeli Facebook reklamlarına tıklayarak alışveriş yapmadaki toplam varyansın $\% 35,2$ 'sini açıklamaktadır. 
Standardize edilmiş regresyon katsayısına $(\beta)$ göre, yordayıcı değişkenlerin Facebook reklamlarına tıklayarak alışveriş yapma davranışına yönelik göreli önem sırası; 13, 10, 5, 12, 3, 9, 8, 4, 7, 1, 2, 11, 6 numaralı değişkenler şeklinde sıralanmaktadır. Regresyon katsayılarının anlamlılığına ilişkin t-testi sonuçları incelendiğinde ise; “Karşı cinsin yer aldığ olmaması" $\{\beta=.21, \mathrm{p}<, 01\}$, "son firsat, sinırlı sayıda, hemen tıkla ve kazan vb. sözcüklerin olması" $\{\beta=.19, \mathrm{p}<, 05\}$, "dikkati çeken ikonlar olması" $\{\beta=$ $-.16, p<, 05\}, \quad$ ilgilenilen bir/ürün hizmet kategorisinde olması" $\{\beta=.12$, $p<, 05\}$, "yazı ve başlıkta ilgimi çekecek bir şey olması" $\{\beta=-.13, p<, 05\}$ ve "kullanılan renklerin hoşa gitmesi" $\{\beta=.12, p<, 05\}$ değişkenlerinin, Facebook reklamlarına tıklayarak alışveriş yapma davranışı üzerinde anlamlı birer yordayıcı olduğu ortaya çıkmaktadır. Diğer değişkenlerin anlamlı birer yordayıcı olmadığı görülmektedir.

Regresyon analiz sonuçlarına göre, Facebook reklamlarına tıklayarak alışveriş yapma davranışının yordanmasına ilişkin regresyon eşitliği ise aşağıda verilmektedir.

Facebook Reklamlarına Tıklayarak Alışveriş Yapma $=0,191+0,027$ (animasyon) + 0,014 (bilimkurgu) + 0,119 (ilgilenilen ürün/hizmet) + 0,090 (ihtiyaç) $+0,189$ (son fırsat) $-0,002$ (bağlantı rengi) $+0,043$ (tıklanma oranını) + 0,112 (renkler) - 0,109 (ilgi çeken) + 0,234 (logo) - 0,003 (görseller) - 0,139 (ikonlar) + 0,238 (karşı cins)

5.4. Haber Akışı Reklamlarının (Paylaşılan Reklamlar) Özellikleri ve Beğenme (Like Etme) Davranışı

Facebook üzerindeki reklamlar sadece Facebook'un kendisinin yayınladığı reklamlardan ibaret değildir. Firmaların, bireysel kullanıcıların yayınladığı, paylaştığı reklamlarda bulunmaktadır. Kullanıcının ana sayfasında, haber akışında görülen, başkalarının paylaştığı bu reklamlar kullanıcılar tarafından beğenilebilme (like'lanabilme) ve paylaşılabilme özelliğine sahiptir. Beğenilebilme/ paylaşılabilme özelliği yüzünden haber akışı reklamları daha fazla kişi tarafından izlenebilme şansına sahip olmaktadır. Araştırmanın bir diğer amacı, haber akışı reklamlarını beğenme davranışında belirleyici reklam özelliklerini tespit etmektir. Başka bir deyişle "sosyal medya söz konusu olduğunda ne tür reklamlar daha fazla beğenilmektedir?" sorusunun cevabı aranmaktadır. Bu amaçla bu tür reklamlar için söz konusu olabilecek çeşitli reklam özelliklerinin her biri ile beğenme (like etme) davranışı değişkeni arasında Çoklu Doğrusal Regresyon Analizi gerçekleştirilmiştir (Tablo 5). 
Tablo 5. Haber Akışı Reklamlarını Beğenme Davranışının Yordanmasına İlişkin Çoklu Regresyon Analizi Sonuçları

\begin{tabular}{|c|c|c|c|c|c|c|c|}
\hline Değişken & B & $\begin{array}{c}\text { Standart } \\
\text { Hata B } \\
\end{array}$ & $\beta$ & $\mathrm{T}$ & $\mathrm{p}$ & İkili $r$ & $\begin{array}{c}\text { Kismi } \\
\mathrm{r}\end{array}$ \\
\hline Sabit & 167 & 106 & - & 1,578 & 115 & - & - \\
\hline $\begin{array}{l}\text { 1.Haber akışımdaki } \\
\text { reklamın komik } \\
\text { olması }\end{array}$ & 263 & ,061 &, 317 & 4,295 & ,000 &, 565 & 206 \\
\hline 2....şaşırtıcı olması &,- 011 & ,072 &,- 014 &,- 155 & 877 & ,532 &,- 008 \\
\hline 3....ilginç olması & ,059 & ,063 & , 074 & ,945 & ,345 &, 529 & ,046 \\
\hline 4....farklı olması &, 053 & ,060 &,- 064 &,- 872 & ,384 &, 504 &,- 043 \\
\hline $\begin{array}{l}\text { 5....zekice tasarlanmış } \\
\text { olması }\end{array}$ &,- 080 &, 054 &,- 101 & $-1,486$ & ,138 &, 425 &,- 073 \\
\hline $\begin{array}{l}\text { 6....müziğinin } \\
\text { beğenilmesi }\end{array}$ &,- 072 & ,051 &,- 086 & $-1,421$ & 156 &, 439 & ,070 \\
\hline $\begin{array}{l}\text { 7....ünlü oyuncuların } \\
\text { oynaması }\end{array}$ &,- 028 & ,051 &,- 033 &,- 549 &, 583 & 460 &,- 027 \\
\hline $\begin{array}{l}\text { 8....sevdiğim } \\
\text { markalarla ilgili } \\
\text { olması }\end{array}$ & 134 & ,053 & 157 & 2,509 & ,012 &, 554 & 122 \\
\hline $\begin{array}{l}\text { 9....ilgilendiğim } \\
\text { ürün/hizmet ile ilgili } \\
\text { olması }\end{array}$ &,- 022 & ,052 &,- 027 &,- 423 & ,672 &, 529 &,- 021 \\
\hline $\begin{array}{l}\text { 10....haber değerinin } \\
\text { olması }\end{array}$ &, 050 &, 046 & ,062 & 1,074 & ,284 &, 526 & ,053 \\
\hline $\begin{array}{l}\text { 11....yabancı bir } \\
\text { reklam olması }\end{array}$ & 119 & ,052 & 119 & 2,303 & ,022 &, 543 & 112 \\
\hline $\begin{array}{l}\text { 12....fiyat avantaj1 } \\
\text { sunmas1 }\end{array}$ & 254 &, 047 & ,290 & 5,425 & ,000 & ,619 & ,257 \\
\hline $\begin{array}{l}\text { 13....yeni ürün reklamı } \\
\text { olması }\end{array}$ & ,034 &, 057 & , 036 &, 596 &, 552 &, 584 & 029 \\
\hline 14....cinsellik içermesi & ,103 &, 045 & 100 & 2,297 & 022 & ,438 & ,112 \\
\hline $\begin{array}{l}\text { 15....toplum yararı } \\
\text { sunan mesajları } \\
\text { olması... }\end{array}$ & ,058 & ,043 & , 076 & 1,336 & ,182 &, 528 & ,065 \\
\hline \multicolumn{8}{|c|}{$\mathrm{R}=, 732 \quad \mathrm{R}^{2}=, 537 \quad \mathrm{~F}(15,415)=32,025 \quad \mathrm{P}=.000$} \\
\hline
\end{tabular}

Haber akışı reklamlarına ilişkin özellikler birlikte, bu tür reklamları beğenme (like etme) davranışı ile orta düzeyde anlamlı bir ilişki vermektedir $\left(\mathrm{R}=0,732, \mathrm{R}^{2}=0,537, \mathrm{p}<.01\right)$. Söz konusu değişkenler birlikte, Haber akış1 reklamlarını beğenme davranışındaki toplam varyansın yaklaşık \% 54'ünü açıklamaktadır. 
Standardize edilmiş regresyon katsayısına $(\beta)$ göre (Tablo 5), yordayıcı değişkenlerin Facebook reklamlarının beğenilmesi üzerindeki göreli önem sırası; 1, 12, 8, 11, 5, 14, 6, 15, 3, 4, 10, 13, 7, 9 ve 2 numaralı değişkenler şeklinde sıralanmaktadır. Regresyon katsayılarının anlamlılı̆̆ına ilişkin $\mathrm{t}$-testi sonuçları incelendiğinde önem sırasına göre "reklamin komik olması", $\{\beta=.31, \mathrm{p}<, 01\}$, "fiyat avantajı sunan bir reklam olması" $\{\beta=.29, \quad p<, 01\}$, "beğendiğim markaların bir reklamı olması" $\{\beta$ $=.15, \mathrm{p}<, 05\}$, "yabancı bir reklam olması" $\{\beta=.11, \mathrm{p}<, 05\}$ ve "reklamda cinsel içerikli görsellerin bulunması" $\{\beta=.10, p<, 05\}$ değişkenlerinin Facebook reklamlarını beğenme davranışı üzerinde anlamlı birer yordayıcı olduğu görülmektedir. Diğer değişkenlerin anlamlı birer yordayıcı değildir.

Regresyon analiz sonuçlarına göre Facebook reklamlarının beğenme davranışının yordanmasına ilişkin regresyon eşitliği ise aşağıda verilmektedir.

Haber Akışı Reklamlarını Beğenme $=0,167+0,263$ (komik)0,011(şaşırtıc1) + 0,059 (ilginç) - 0,053 (farklı gelmesi) - 0,080 (zekice) 0,072 (müzik) - 0,028 (ünlü oyuncular) $+0,134$ (beğendiğim marka) 0,022 (ilgi alanıma girme) $+0,050$ (haber) $+0,119$ (yabanc1) $+0,254$ $($ avantajlı) $+0,034$ (yeni çıkan) $+0,103$ (cinsellik) $+0,058$ (toplum yararı).

\subsection{Reklamların (Paylaşılacak Reklamlar) Özellikleri ve Reklam} Paylaşma Davranışı

Facebook kullanıcılarına birer reklam yayıncısı olma firsatı da vermektedir. Kullanıcılar Facebook üzerinde gördükleri başkalarının paylaşmış olduğu reklamları ya da başka mecralarda (YouTube, Dailymotion vb.) yayınlanan reklamları paylaşarak yayınlayabilmektedirler. $\mathrm{Bu}$ araştırma "ne tür reklamların daha fazla paylaşıldığını" da araştırmaktadır. Bu amaçla çeşitli reklam özellikleri ile reklam paylaşma davranışı değişkenleri arasında Çoklu Doğrusal Regresyon analizi gerçekleştirilmiştir (Tablo 6). 
Tablo 6. Facebook'ta Reklam Paylaşma Davranışının Yordanmasına İlişkin Çoklu Regresyon Analizi Sonuçları

\begin{tabular}{|c|c|c|c|c|c|c|c|}
\hline Değişken & B & $\begin{array}{l}\text { Standart } \\
\text { Hata B }\end{array}$ & $\beta$ & $\mathrm{T}$ & $\mathrm{p}$ & İkili r & $\begin{array}{l}\text { Kis } \\
\text { mi r }\end{array}$ \\
\hline Sabit & 071 & ,095 & - & ,741 & ,459 & - & - \\
\hline $\begin{array}{l}\text { 1.Reklamın komik } \\
\text { olması }\end{array}$ & ,373 & ,058 & ,411 & 6,420 & ,000 & 717 & ,301 \\
\hline 2....ş̧aşırtıcı olması & ,004 & ,079 & ,004 & ,045 & ,964 & 679 & ,002 \\
\hline 3....ilginç olması & ,125 & 079 & 140 & 1,584 & ,114 & 672 & ,078 \\
\hline 4....farklı olması &,- 025 & ,064 &,- 028 &,- 396 & ,692 & 635 &,- 019 \\
\hline $\begin{array}{l}5 . . . \text { zekice } \\
\text { tasarlanmış olması }\end{array}$ &,- 021 &, 060 &,- 025 &,- 356 & ,722 & 610 &,- 018 \\
\hline $\begin{array}{l}\text { 6....müziğinin } \\
\text { beğenilmesi }\end{array}$ & ,042 & ,049 & ,045 & ,862 & ,389 & ,559 & ,042 \\
\hline $\begin{array}{l}\text { 7....ünlü oyuncuların } \\
\text { oynaması }\end{array}$ &,- 233 & ,058 &,- 227 & $-4,044$ & , 000 & ,490 &,- 195 \\
\hline $\begin{array}{l}8 \ldots \text { sevdiğim } \\
\text { markalarla ilgili } \\
\text { olması }\end{array}$ & ,212 & ,061 & ,218 & 3,475 & ,001 & 619 & 169 \\
\hline $\begin{array}{l}\text { 9....ilgilendiğim } \\
\text { ürün/hizmet ile ilgili } \\
\text { olması }\end{array}$ &,- 060 & 054 &,- 067 & $-1,108$ & ,269 &, 599 &,- 054 \\
\hline $\begin{array}{l}\text { 10....haber değerinin } \\
\text { olmas1 }\end{array}$ & ,086 & ,060 & ,098 & 1,426 & ,155 & 630 & ,070 \\
\hline $\begin{array}{l}\text { 11....yabancı bir } \\
\text { reklam olması }\end{array}$ &,- 070 & ,061 &,- 062 & $-1,150$ & ,251 & ,502 &,- 056 \\
\hline $\begin{array}{l}\text { 12....fiyat avantaj1 } \\
\text { sunmas1 }\end{array}$ & 018 & ,060 & ,017 & 297 & ,767 & ,588 & 015 \\
\hline $\begin{array}{l}\text { 13....yeni ürün } \\
\text { reklamı olmas1 }\end{array}$ & ,004 & ,061 & ,004 & ,063 & 950 &, 583 & ,003 \\
\hline 14...cinsellik içermesi & 230 & ,055 & ,187 & 4,147 & ,000 &, 504 & 200 \\
\hline $\begin{array}{l}\text { 15....toplum yararı } \\
\text { sunan mesajları } \\
\text { olması... }\end{array}$ &,- 039 & ,052 &,- 046 &,- 747 & ,456 &, 560 &,- 037 \\
\hline $\begin{array}{l}\text { 16....bir yeniliği } \\
\text { duyurması }\end{array}$ & 117 & ,057 & ,128 & 2,058 & ,040 & 601 & 101 \\
\hline $\begin{array}{l}\text { 17...."son fırsat", } \\
\text { "sınırlı sayıda", } \\
\text { "hemen tıkla kazan" } \\
\text { vb. ibareler içermesi... }\end{array}$ & 132 & ,055 & 119 & 2,412 & ,016 &, 562 & ,118 \\
\hline
\end{tabular}


Haber akışı reklamlarına ilişkin özellikler birlikte, bu tür reklamları paylaşma davranışı ile orta düzeyde anlamlı bir ilişki vermektedir ( $R=0,789$, $\mathrm{R}^{2}=0,623, \mathrm{p}<.01$ ). Söz konusu değişkenler birlikte, reklam paylaşma davranışındaki toplam varyansın yaklaşık \%62'sini açıklamaktadır.

Standardize edilmiş regresyon katsayısına $(\beta)$ göre, yordayıcı değişkenlerin Facebook'ta reklam paylaşma davranışı üzerindeki göreli önem sırası şu şekilde ortaya çıkmaktadır: 1, 7, 8, 14, 3, 16, 17, 10, 9, 11, 15, 6, 4, 5, 12, 13, 2 numaralı değişkenler. Regresyon katsayılarının anlamlılığına ilişkin t-testi sonuçları incelendiğinde önem sırasına göre; "reklamın komik olması", $\{\beta=.41, \mathrm{p}<, 01\}$, "sevilen ünlü oyuncuların reklamda oynaması" $\{\beta=-.22, p<, 01\}$, "beğenilen markaların bir reklamı olması" $\{\beta=.18, p<, 05\}$, "reklamda cinsel içerikli görsellerin bulunması" $\{\beta=.18, p<, 01\}$, "bir yeniliği duyurması" $\{\beta=.12, \mathrm{p}<, 05\}$ ve "son firsat, sinırlı sayıda, hemen tıkla ve kazan vb. sözcüklerin yer alması" $\{\beta=.11, \mathrm{p}<, 05\}$ değişkenlerinin, Facebook reklamlarını paylaşma davranışı üzerinde anlamlı birer yordayıcı olduğu ortaya çıkmaktadır. Diğer değişkenlerin anlamlı birer yordayıcı olmadığı görülmektedir.

Regresyon analiz sonuçlarına göre Facebook reklamlarını paylaşma davranışının yordanmasına ilişkin regresyon eşitliği ise aşağıda verilmektedir.

Facebook'ta Reklam Paylaşma Davranışı $=, 071+0,373$ (komik) + 0,004 (şaşırtıc1) + 0,125 (ilginç) - 0,025 (farklı gelmesi) - 0,021 (zekice) + 0,042 (müzik) - 0,233(ünlü) +0,212 (beğenilen marka) - 0,060 (ilgi alanı) + 0,086 (haber) - 0,070 (yabancı) $+0,018$ (fiyat avantaj1) $+0,004$ (yeni çıkan) + 0,230 (cinsel içerik) - 0,039 (toplum yararı) + 0,117 (yenilik) + 0,132 (son firsat).

5.6. Facebook'ta Reklamlara T1klama, Beğenme ve Paylaşma Davranışı ile Reklamlarda Görülen Ürün/Markaları Satın Alma Davranışı

Araştırmanın ilgilendiği bir diğer sorun ise Facebook reklamlarına tıklama, onları beğenme ve paylaşma davranışlarının Facebook üzerinde görülen reklamlardaki ürünleri/markaları satınalma davranışını yordayıp yordamadığıdır. Bununla ilgili olarak tıklama, beğenme ve paylaşma değişkenleri ile satın alma davranışı değişkenleri arasında Çoklu Doğrusal Regresyon analizi gerçekleştirilmiştir (Tablo 7). 
Tablo 7. Facebook Reklamlarındaki Ürün/Markaları Satın Alma Davranışının Yordanmasına İlişkin Çoklu Regresyon Analizi Sonuçları

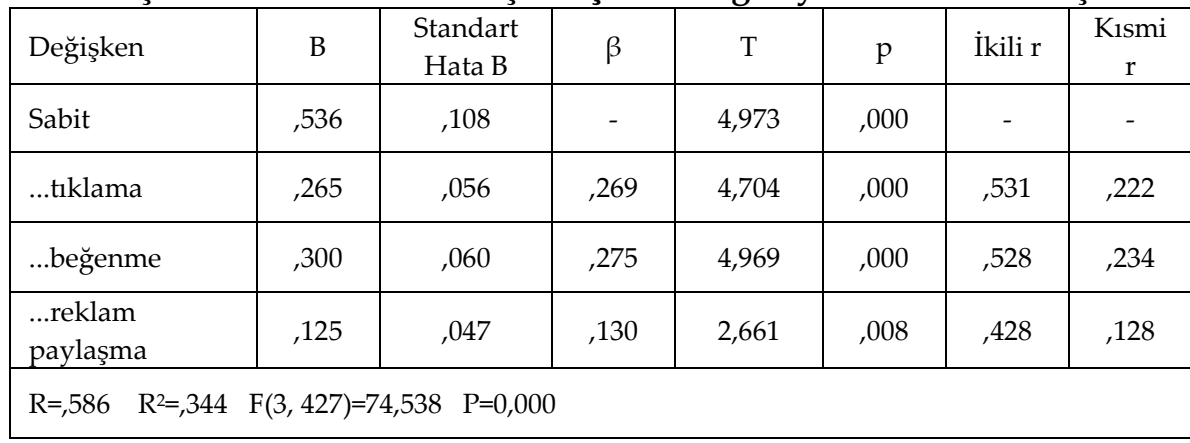

Facebook reklamlarına tıklama, beğenme ve paylaşma davranışı değişkenleri birlikte, satın alma davranışı ile düşük düzeyde anlamlı bir ilişki vermektedir. ( $R=0,586, R 2=0,344, p<.01)$. Söz konusu değişkenler birlikte satın alma davranışındaki toplam varyansın yaklaşık \%35'ini açıklamaktadır.

Standardize edilmiş regresyon katsayısına ( $\beta$ ) göre, yordayıcı değişkenlerin satın alma davranışı üzerindeki göreli önem sırası; Facebook reklamlarını beğenme, tıklama ve paylaşmanın değişkenleri şeklindedir.

Tablo 7'de regresyon katsayılarının anlamlılığına ilişkin t-testi sonuçları incelendiğinde önem sırasına göre; "Facebook reklamlarını beğenme", $\{\beta=.27, \mathrm{p}<, 01\}$, “Facebook reklamlarına tıklama" $\{\beta=.26, \mathrm{p}<, 01\}$ ve "Facebook'ta reklam paylaşma" $\{\beta=.13, p<, 05\}$ değişkenlerinin tamamının satın alma davranışı üzerinde anlamlı birer yordayıcı olduğu ortaya çıkmaktadır.

Regresyon analiz sonuçlarına göre satın alma davranışının yordanmasına ilişkin regresyon eşitliği şu şekildedir: Facebook Reklamlarındaki Ürünleri Satın Alma $=0,536+0,265$ (tıklama) $+0,300+$ (beğenme) + 0,125 (paylaşma).

\section{Sonuç}

Facebook'un reklam sistemi reklamverene çok çeşitli bir reklam alternatifleri listesi sunmaktadır. Bu aynı zamanda kullanıcının da çok farklı şekillerde reklama maruz kalmaları, bunun yanında reklama çok farklı biçimlerde tepki verme imkânına sahip olması anlamına gelmektedir. Bir sosyal medya olarak Facebook'ta reklamın belki de en önemli avantaji bu reklam yapma imkanının çeşitliliğinin yanında, kullanıcıları aktif birer 
reklam yayıncısı ve promosyon katılımcısı olarak sürece katmasıdır. Her kampanya da beklenen etki farklı olabilir. Bu yüzden etkinin göstergeleri de farklıdır. Bazı reklam uygulamalarında amaç iş sayfasının farkındalığının yükseltilmesi, sayfanın fanlarının artması iken, bazılarında doğrudan satış yapmaktır. Facebook hem doğrudan pazarlamaya hem de ilişkisel pazarlamaya imkân tanıyan bir sisteme sahiptir.

$\mathrm{Bu}$ araştırma ister ilişkisel ister doğrudan pazarlama amacıyla yola çıkılmış olsun, bu reklamlara tüketicilerin tepkilerini belirleyen reklamla ilgili önemli faktörleri ortaya çıkarmak amacıyla tasarlanmıştır. Pazarlamacılar ve reklamcılar Facebook'u ya onun ücretsiz araçlarından faydalanarak, ya da diğer mecralarda olduğu gibi reklam alanı kiralamak kaydıyla kullanmaktadır. Buna dayanarak bu çalışma, Facebook reklamlarını "ödemeli (sponsorlu) reklamlar" ve "haber akışı reklamları" olarak iki grupta ele almış, bu iki gruptaki reklamların ne tür özelliklerinin reklam beğenme, paylaşma, tıklama ve satın alma davranışlarında görece daha önemli olduğunu araştırmıştır. Ödemeli Facebook reklamları söz konusu olduğunda kullanıcılar ilgilendikleri bir ürün kategorisine ait, tıklanma oranının yüksek, bilim kurgu tarzı, değişik renk ve yazılı bağlantılara sahip reklamlara tıklamaktadır. Kullanıcılar ayrıca bu tür ödemeli reklamlar söz konusu olduğunda, daha çok karşı cinsin yer aldığı, reklamverenin kimliğini açıkça göremedikleri, "son fırsat", "hemen tıkla kazan" gibi çekici çağrıların yer aldığı, dikkat çekici ikonları olan, ilgilendikleri bir ürün/hizmetin reklamlarına tıklayarak satın alma davranışını gerçekleştirmektedirler.

Araştırma Facebok üzerinde kullanıcının haber akışında görülen ne tür reklamların daha çok beğenildiğine de odaklanmaktadır. Araştırma bulgularına göre, bu tür reklamlar söz konusu olduğunda komik, fiyat avantajı vaat eden, beğenilen markalara ait, yabancı, cinsel içeriğe sahip reklamlar daha çok beğeni almaktadır.

Facebook'un önemli bir özelliği kullanıcılara reklam yayıncısı olma imkânı sunmasıdır. Bu araştırma ne tür reklamların paylaşıldığı sorununa da odaklanmaktadır. Araştırma bulgularına göre, kullanıcılar daha çok komik, ünlü oyuncuların oynadığı, beğendikleri markalara ait, cinsel içerikli, bir yeniliği duyuran ve ayrıca 'son fırsat', 'sınırlı sayıda', 'hemen tıkla, kazan' gibi çekici çağrıların bulunduğu reklamları paylaşmayı tercih etmektedir.

Son olarak Facebook reklamlarına tıklama, beğenme ve paylaşma davranışlarının herhangi bir tür Facebook reklamında görülen markaları satın alma davranışı ile ilişkisi olup olmadığı bu araştırmanın odağındadır. 
Araştırma bulgularına göre, kullanıcılar paylaştıkları, beğendikleri ya da tıkladıkları Facebook reklamlarında gördükleri markaları satın almaktadır.

\section{Kaynakça}

"Facebook Reklamları İe Etkileşimde Bulunma" http://www.facebook.com/help/interacting-with-ads. Erişim Tarihi: 16.07.2014.

"Paid Social Media Advertising, Industry Update and Best Practices Report 2013, Vizu-Nielsen Company, http://www.nielsen.com/.../NielsenPaid-Social-Media. Erişim Tarihi: 19.07.2014.

Blackshaw Pete, \& Nazzaro Mike (2006). "Consumer-Generated Media (CGM) 101: Word-of-Mouth in the Age of the Webfortified Consumer". A Nielsen BuzzMetrics White Paper Second Edition, Spring, http://www.nielsen-online.com/.../nbzm_wp_CGM10.. Erişim Tarihi: 18.07.2014.

Büyükşener Ercüment (2009). “Türkiye'de Sosyal Ağların Yeri ve Sosyal Medyaya Bakış", İnet-tr'09-XIV.Türkiye'de İnternet Konferansı Bildirileri, 12-13 Aralık 2009, Bilgi Üniversitesi İstanbul.

Dunay Paul, Krueger Richard and Elad Joel (2011). Facebook Advertising for Dummies, Wiley Publishing Inc. Indiana.

Goyal Sumit (2012). "Facebook, Twitter, Google+: Social Networking", International Journal of Social Networking and Virtual Communities, 1 (1):16-18.

Goyal Sumit (2013). "Advertising on Social Media", Scientific Journal of Pure and Applied Sciences, 2(5): 220-223.

Kaplan, A.M. and Haenlein, M. (2010) "Users of the world, unite! The challenges and opportunities of Social Media", Business Horizon, 53(1), 59-68.

Kara Yasemin ve Coşkun Ali (2012). "Sosyal Ağların Pazarlama Aracı Olarak Kullanımı: Türkiye'deki Hazır Giyim Firmaları Örneği", Afyon Kocatepe Üniversitesi, İ̈BF Dergisi, 15 (2): 73-89.

Mangold W. Glynn and Faulds David J. (2009). "Social Media: The New Hybrid Element of the Promotion Mix", Business Horizons, 52: 357365.

Mon E. Gonzalo (2013). "Advertising and Promotions in Social Media", Practical Law the Journal Transactions \& Business, October: 43-51. http://us.practicallaw.com/2-383-6690. Erişim Tarihi: 17.07.2014. 